DOI: 10.26693/jmbs05.05.223

UDC 004.451.661:378.147:616-052-047.37:004

Pyatchanina T., Ogorodnyk A., Melnik-Melnikov P., Gerasymchuk S.

\title{
Commercialization Capability of R\&D Results in Biomedical Field of Ukraine and Analysis of Related Foreign Experience
}

\author{
RE Kavetsky Institute of Experimental Pathology, Oncology and Radiobiology \\ of the National Academy of Sciences of Ukraine, Kyiv, Ukraine
}

kassmail@ukr.net

Rapid development of modern areas of biomedical science contributes to the increase of the implementation rate, of innovative products and services in medicine, in particular, clinical oncology.

The purpose of the article is the comparative analysis of the experience of R\&D results commercialization in biomedical sector of the developed countries and Ukraine. The study uses methods of structural and logical analysis and comparative content analysis.

Commercialization fits the inventor interests in using intellectual property, provides its implementation, and reveals commercial advantages to continue scientific and innovative activity. Society is interested in successful commercialization and technology transfer in biomedical field that increase competitiveness level of health system. Such activity stimulates scientists to develop innovative products.

In foreign countries, legal and organizational mechanisms have been created that stimulate of investment activities for conducting research in the biomedical science at universities and scientific institutions. The development of links in the field of commercialization of R\&D results has become a priority of the innovation policy of many countries, and public-private partnerships are an effective tool for its implementation, as evidenced by the rising of national budgets, legislative initiatives and the development of new programs.

The analysis of the foreign experience of technology transfer of medical and biological R\&D results allows to highlight several points: the financial support of research institutes and universities is considered as an important function of the state; public financing of projects in the field of medicine and biology is carried out within a quite long period of time (often not less than 10 years), and the purchase of equipment is not a central item of expenditures; assessment of the productivity of researchers is complemented by evaluating the performance of the departments responsible for research management and funding; quantitative indicators of research unit results are supplemented by expert assessments of the quality of research, effectiveness and safety of medical developments based on new knowledge and achievements of scientific and technological progress.
Conclusion. In Ukraine, despite certain difficulties in recent years, the high scientific potential in the field of biomedical sciences provides an increase of the number of high-tech innovative scientific and technological developments. Taking into account the low innovative activity of scientific institutions and universities, commercialization requires a systematic state approach, the development of strategies, specific mechanisms, methods and forms.

Keywords: commercialization, technology transfer, scientific and technical activities (R\&D activities), innovative product, biomedical science.

Connection of work with scientific programs, plans, topics. The study was performed in accordance with the R\&D of the Department of Research Management and Innovation of the RE Kavetsky Institute of Experimental Pathology, Oncology and Radiobiology of the National Academy of Sciences of Ukraine "Development of strategies for technology transfer in oncology practice, taking into account the specifics of Ukraine", state registration № $0119 U 103932$.

Introduction. Current rapid development of biomedical science contributes to development of innovative products and services in domestic scientific research institutes and universities. Such significant assets in the form of intellectual property (IP), being effectively commercialized, would provide significant progress in social sectors of economy, such as healthcare, pharmacology, biotechnology etc.

Implementation of innovative products developed by scientific research institutes and universities involved in biomedical research is hampered by insufficiently developed state mechanisms of R\&D results commercialization. Lack of such mechanisms negatively affects financial situation in the research institutions particularly in terms of laboratory equipment upgrading, participation in foreign scientific forums, employee training, investment in future innovations.

The challenges for the development of Ukrainian innovation capacity have been analyzed in scientific literature [1]. Among factors that negatively affect implementation of R\&D results in biomedical sector are the following ones: ineffective patent and innovation policy, low organizational and marketing activity, lack 
of close interaction between science and clinics, lack of qualified innovation personnel capable to carry out comprehensive expertise of biomedical innovation, challenges in innovation marketing and finding potential investors and partners, i.e. actions in the frame of biomedical $R \& D$ results commercialization.

Despite of above mentioned challenges one of the main purposes of domestic biomedical research institutes and universities is to enhance implementation capacity of R\&D results. Learning of successful TT experience and mechanisms, exploring the ways to cope with TT challenges in the leading scientific centers, where TT offices (OTT) are established to manage such activity and could facilitate the above mentioned main purpose [2].

Objective: Comparative analysis of the experience of $R \& D$ results commercialization in biomedical sector of the developed countries and Ukraine.

Material and methods. Analysis of scientific literature containing TT and R\&D commercialization of the Ukrainian and foreign scientists has been carried out. The methods of structural-logical and comparative content analysis of the international and domestic patent databases have been selected for the methodological basis for the study [3].

Results and discussion. TT and commercialization of R\&D results in biomedical field is the most important part of innovative process of transforming biomedical R\&D results into innovative product with its implementation into medical practice. As a process, TT and commercialization envisages a variety of mechanisms, involving stakeholders with vision, motivation, technical capabilities, scientific potential and sufficient financing [4].

Nowadays, R\&D results in biomedical field become valuable assets, that being commercialized, would contribute to health system development and quality improvement of human life and might be one of the sources for science funding. R\&D results commercialization depends on many factors, such as ability of scientific institutes and universities to develop competitive R\&D results; demand for IP; level of economic development; institutional and legal capacities; state innovation policy to support export of scientific products and services.

Theoretical and practical aspects of technology transfer process are subject of research in many countries around the world. Experience of R\&D results TT of such organizations as PATH (Program for Appropriate Technology in Health), OTT of NIH (Office of Technology Transfer of National Institutes of Health, USA), Stanford University OTT and MIT OTL has been reviewed in [2]. Such international associations as LES-International (Licensing Executives Society), AUTM (Association of University Technology Managers), ASTP (Association of Science and Technology
Transfer Professionals, EU) promote TT knowledge and experience, offer training courses for OTT specialists. The experience of the best OTT as well as OTT establishment and operation were analyzed in Ukrainian-language sources, for example, in [12].

Scientists propose different approaches in defining commercialization of R\&D results in the various areas - such as a method, a process, a financial tool [5]. They focus on the study of complex issues of IP management and on the essential aspects of commercialization, stages of the process. The commercialization of R\&D results obtained at universities is generally considered as a transformation of the R\&D results with market attractiveness for the purpose of licensing or start-up creation.

Commercialization results in assessing and selecting innovations, fundraising, IP legal protection and implementation into production [5].

Commercialization processes of IP objects have been most extensively studied, however, the issues of TT in medicine and biology have remained less analyzed in Ukraine. The complexity of the biomedical TT in Ukraine is caused by the lack of developed mechanisms, tools, forms and methods for the interconnection with the industry, as well as the undeveloped legislative framework in this field.

The problem of IP commercialization in the field of pharmacology was investigated in detail by domestic scientists [6] and methodological approaches were established towards the improvement in patent information activity during development of medicines. Researchers $[4,7]$ perceive commercialization as mutually beneficial activities of pharmaceutical market entities to realize their IP rights in the process of transforming the results of IP into a socially important market product.

Issues related to development of information support system for scientific and innovative activity in biomedical field have been analyzed in the following work [7]. The author studies areas of information support and analyzes communication mechanisms to improve the efficiency of commercialization of biomedical developments.

Unfortunately, scientific research of biomedical $R \& D$ commercialization is characterized by lack of holistic models and systematic scientific approaches in Ukraine. Publications of domestic authors explore mostly some aspects of this issue.

The analysis of foreign experts works shows that there is a state support for setting up close links between industry and scientific centers for pubic benefit. One of the functions of foreign biomedical research institutions is state financial support for research projects. The following examples of such foreign institutions are: National Institutes of Health of the United States of America, the Canadian Institutes of Health, 
the National Institutes of Health of Great Britain, the Institute of France, etc. (http://lib.nuph.edu.ua). Despite the different approaches to commercialization of biomedical R\&D results in these institutions, a common characteristic is leading role in identifying priority areas for biomedical research in their countries. In this regard, the most complete embodiment of the commercialization model in biomedical research organizations is observed in the USA. The US National Institutes of Health functions as the national agency for Medical and Health Research, comprising 27 institutes and centers, each with its own research agenda focused on combating specific diseases or specific group of nosologies [8].

The productivity of the TT system, including biomedical innovation in the world, is receiving considerable attention as $38 \%$ of US GDP is generated through IP and patents that brought \$6 trillion in 2016. TT includes identification of promising technologies, technical solutions, investment in their development and launch of a new product (service) on the market. The concept of TT is a "transition" of R\&D results from the field of basic research to effective practical implementation. The base for the development of TT infrastructure is Legislative framework, namely, the Bayh-Dole Act (1980), which in the long run helped to improve science-business communication, increased licensing and formation of innovative joint ventures, start-ups and spin-offs [9]. The law created the basis for a uniform federal patent policy, providing universities and national laboratories with property rights to inventions created under federal funding. As a result, USA has obtained rapid increase in the number of patents issued annually and comprehensive development of IP comparing with previous decades. In the US, the patent system of national laboratories and universities has a significant impact on the country's economic growth. IP protection and commercialization of the R\&D results serves as means of: inventors' financial support, establishing profitable links with industry, and attracting investment in research projects.

In Germany, the integration of national scientific and technical policy with state industrial policy is based on state support for staff exchanges and the development of public-private partnerships [10]. The Helmholtz Association of German Research Centers consists of 19 research centers, including biomedical science centers (www.helmholtz.de) which are engaged in the commercialization of biomedical R\&D results. One of the important tasks of organization is motivation of university professors and specialists for entrepreneurial activity for the purpose of commercialization. Leibniz Association unites together 96 research organizations that deal with research issues of public concern. Research institutes that create infrastructure for science also provide such services as partner search, consultancy and knowledge transfer for NGOs (www.leibniz-association.eu). The Max Planck Society (MPG) (https://www.mpg.de), which brings together about 80 fundamental research institutes across Germany, plays an important role in the commercialization of the R\&D results. They are funded by the government, which, as one of the major indicators for evaluating the effectiveness of its investments in MPG's activities, considers the creation of spin-off companies as tools for the commercialization of innovative products.

In Finland the leading role in commercializing $R \& D$ results in the field of medicine and biology is played by the Finnish Technology and Innovation Support Fund "Business FINLAND" (until 2018 it was called Tekes (https://www.businessfinland.fi/en/) and the Finnish Innovation Fund SITRA (https://www.sitra. fi/en/) independent public foundation which operates directly under the supervision of the Finnish Parliament, whose tasks are: to find commercially attractive ideas in universities and research centers, to provide investment in the early stages of start-ups, to finance the development of business plans, to expand international cooperation between research entities.

Sweden is a world leader in some fields of medical science (such as neuroscience), and is one of the leaders by the number of scientific publications and patents in the field of medical sciences [8] 3.6\% of GDP is channeled to R\&D funding, state financial support is given directly to universities and research institutes through research program grants. The leading institute in medical science is the Karolinska Institute from Stockholm (https://www.masterstudies.com/ universities/Sweden/Karolinska-Institutet/), which leads about $43 \%$ of all medical research.

France has a National Research Strategy - Europe 2020 (French La stratégie nationale de recherché France - Europe 2020) (https://stip.oecd.org), which is designed in accordance with the Higher Education and Research Act, and defines four areas: "Big Data or Megadata", "Energy, Environment and Sustainability", "Life and Health", "Human and Society", outlines 15 priority directions of studies. The research direction "Health and Wellbeing" covers biology, physiology, medicine. Health research is a major public policy priority. The theme of health and wellbeing is represented in more than a third of all French research organizations and universities. Priority direction "From the laboratory to the patient" provides fundamental and clinical studies of multifactorial, chronic and infectious diseases, rare diseases, disabilities.

The analysis of the foreign experience of TT of medical and biological R\&D results allows to highlight several points: the financial support of research institutes and universities is considered as an important function of the state; public financing of projects in the 
field of medicine and biology is carried out within a quite long period of time (often not less than 10 years), and the purchase of equipment is not a central item of expenditures; productivity assessment of researchers is complemented by evaluating the performance of the departments responsible for research management and funding; quantitative indicators of research units results are supplemented by expert assessments of the quality of research, effectiveness and safety of medical developments based on new knowledge and achievements of scientific and technological progress [11].

State and priority directions of tech transfer development in Ukraine. In Ukraine, according to the State Statistics Service in 2018 [12] with total number of 77,5 thousand scientists R\&D projects aimed at creation of new products, technologies and materials. Among them, 37,6 thousand projects on the development of new types of products were completed, including 17,6 thousand new types of machinery, 33,2 thousand new technologies and 6,8 thousand new types of materials. A considerable part of them was financed from the state budget. The level of commercialization of the results of scientific and technical activities does not meet the requirements of the declared innovation-oriented economic development. Experts in this area identified [1] more than 50 possible factors of low commercialization and TT level. They are conventionally divided into five major groups, including: lack of competence of the subjects of innovation activity; insufficient financing of innovative activity; shortcomings of the regulatory framework of innovation activity; lack of effective innovation infrastructure; inefficient innovation management
According to scientists $[5,13]$ one of the main reasons is the lack of a systematic approach to innovation management at both macro and micro levels. Scientific organizations, public authorities carry out the functions of planning, organizing, motivating and controlling innovative activities at their level. Priority areas for increasing the efficiency of commercialization of domestic biomedical scientific research, which are created at the expense of state funds, include the following: creation and development of centers of commercialization and TT, business incubators, specialized technoparks for universities and research institutes; development of mechanisms and creation of a system of venture capital investment; stimulation and support of cooperative links between research organizations and industry based on the formation of programs and projects for the development and release of innovative products [14].

Conclusion. The comparative analysis of domestic and foreign experience of biomedical R\&D results commercialization shows that there is a high level of development in economically developed countries, which is provided, first of all, by state support for forming close ties between business and research institutes and universities to create new techcenters of technology that make extensive use of various mechanisms and forms of technology transfer.

In Ukraine, despite the considerable difficulties and barriers between high scientific potential, on the one hand, and low innovation activity of research organizations, on the other, there is an increase of high-tech innovative scientific and technological developments in the field of biomedical sciences. Their ccommercialization requires systematic state approach to the development of strategies, specific mechanisms, methods and forms.

\section{References}

1. Tsibulev PM, Korsun VF. Bariery na shliakhu komertsializatsii rezultativ naukovykh doslidzhen v Ukraini [Barriers to commercialization of research results in Ukraine]. Science and innovation. 2009; 5(6): 87-96. [Ukrainian]

2. Melnik-Melnikov P, Pyatchanyna T, Ogorodnyk A. Analysis of foreign tech transfer offices experience for the effective tech transfer system formation in the Ukrainian scientific institutions. Science, Technologies, Innovations. 2019; 3(11): 62-69. [Ukrainian]

3. Vazhytskyi SE, Shcherbak TI. Metodyka ta orhanizatsiia naukovykh doslidzhen [Methodology and organization of scientific research]. Sumy: SumDPU im. A.S. Makarenka; 2016. 260 s. [Ukrainian]

4. Tsibulev PM, Chebotarov VP, Zinov VG, Suini Yu. Upravlinnia intelektualnoiu vlasnistiu [Intellectual property management]. K: KIC; 2005. s. 435-442.

5. Novikova IE, Beduh OR, Zenova MV. Rozvytok systemy transferu tekhnolohii u KNU im. Tarasa Shevchenka v konteksti yevrointehratsii [Development of technology transfer system at KNU Taras Shevchenko in the context of European integration]. KNUTD Bulletin. 2016; 2(97): 63-70. [Ukrainian]

6. Litvinova OV, Posylkina OV. Upravlinnia intelektualnymy resursamy u farmatsii v umovakh innovatsiinoho rozvytku [Management of intellectual resources in pharmacy in the conditions of innovative development]. Kh: NFaU; 2018. 360 p. [Ukrainian]

7. Artamonova NO. Informatsiine zabezpechennia transferu medychnykh tekhnolohii yak suchasnyi komunikatsiinyi mekhanizm innovatsiinoi diialnosti [Information support of medical technology transfer as a modern communication mechanism of innovative activity]. Bibliotekoznavstvo. Dokumentoznavstvo. Informolohiia. 2009; 3: 56-66. [Ukrainian] 
8. Servoss J. The Early Tech Development Course: Experiential Commercialization Education for the Medical Academician. Acad Med. 2017; 92(4): 506-510.

9. The Bayh-Dole Act or Patent and Trademark Law Amendments Act (Pub. L. 96-517, December 12, 1980). Available from: https://www.gao.gov/archive/1998/rc98126.pdf

10. International Co-operation in Research and Innovation. Available from: https://www.kooperation-international. de/fileadmin/redaktion/publication/titel_bufi_engl_end.pdf

11. Lyashenko OM. Modeli komertsializatsii ta transferu tekhnolohii v umovakh hlobalnoho seredovyshcha [Models of commercialization and technology transfer in the global environment: monograph]. Ternopil; 2007.489 p. [Ukrainian]

12. Scientific and Innovative Activity of Ukraine: Statistical Collection. 2018. [Ukrainian]. Available from: http://www. ukrstat.gov.ua/]

13. Koval I. [Problems of commercialization of intellectual property rights by higher education institutions]. The theory and practice of intellectual property. 2014; 4: 11-18. [Ukrainian]

14. Denisyuk VA. Komertsializatsiia rezultativ naukovo-doslidnykh robit: problemy i perspektyvy [Commercialization of research results: problems and perspectives]. Bulletin of the National Academy of Sciences of Ukraine. 2006; 5: 45-50. [Ukrainian]

\section{УДК 004.451.661:378.147:616-052-047.37:004}

\section{МОЖЛИВІСТЬ КОМЕРЦІАЛІЗАЦІЇ РЕЗУЛЬТАТІВ НАУКОВИХ ДОСЛІДЖЕНЬ} У СФЕРІ МЕДИКО-БІОЛОГІЧНИХ НАУК В УКРАЇНІ ТА АНАЛІЗ ЗАКОРДОННОГО ДОСВІДУ

\section{П'ятчаніна Т. В., Огородник А. М., Мельник-Мельников П. Г., Герасимчук С. М.}

Резюме. Сучасний розвиток медико-біологічної науки сприяє підвищенню темпів імплементації інноваційної продукції та послуг в медичну галузь, зокрема, в клінічну онкологію.

Метою статті є порівняльний аналіз досвіду комерціалізації результатів наукової діяльності в медико-біологічній галузі в найбільш розвинених країнах і в Україні. Були використані методи структурнологічного та порівняльного контент-аналізу.

У комерціалізації медико-біологічних науково-технічних розробок зацікавлені розробники інновацій і суспільство в цілому. Цей процес сприяє підвищенню конкурентоспроможності охорони здоров'я, а також комерціалізація виявляє ринкові переваги науково-технічних розробок і відповідає майновим інтересам вчених щодо використання об'єктів інтелектуальної власності. У розвинених зарубіжних країнах створені правові та організаційні механізми, що стимулюють розвиток інвестиційної діяльності для проведення в закладах вищої освіти і наукових установах досліджень в медико-біологічній галузі. Розгортання зв'язків у сфрері комерціалізації науково-технічних розробок стало пріоритетом інноваційної політики багатьох держав, а приватно-державні партнерства - дієвим інструментом ії̈ реалізації, про що свідчить зростання витрат національних бюджетів, законодавчих ініціатив і розробки нових програм.

В Україні, незважаючи на певні труднощі останніх років, високий науковий в галузі медико-біологічних наук забезпечує зростання кількості наукомістких інноваційних науково-технічних розробок, комерціалізація яких, з урахуванням низької інноваційної активності наукових установ і закладів вищої освіти, вимагає системного державного підходу, розробки стратегій, конкретних механізмів, способів і форм.

Ключові слова: комерціалізація, трансфер технологій, науково-технічна діяльність, інноваційний продукт, медико-біологічна галузь.

\section{УДК 004.451.661:378.147:616-052-047.37:004 \\ ВОЗМОЖНОСТЬ КОММЕРЦИАЛИЗАЦИИ РЕЗУЛЬТАТОВ НАУЧНЫХ ИССЛЕДОВАНИЙ В СФЕРЕ МЕДИКО-БИОЛОГИЧЕСКИХ НАУК В УКРАИНЕ \\ И АНАЛИЗ ЗАРУБЕЖНОГО ОПЫТА}

Пятчанина Т. В., Огородник А. Н., Мельник-Мельников П. Г., Герасимчук С. М.

Резюме. Современное развитие медико-биологической науки способствует повышению темпов имплементации инновационной продукции и услуг в медицинскую отрасль, в частности, в клиническую онкологию.

Целью статьи является сравнительный анализ опыта коммерциализации результатов научной деятельности в медико-биологической отрасли в наиболее развитых странах и в Украине. Были использованы методы структурно-логического и сравнительного контент-анализа.

В коммерциализации медико-биологических научно-технических разработок заинтересованы разработчики инноваций и общество в целом. Этот процесс способствует повышению конкурентоспособности здравоохранения, а также коммерциализация выявляет рыночные преимущества научно-технических разработок и отвечает имущественным интересам ученых по использованию объектов 
интеллектуальной собственности. В развитых зарубежных странах созданы правовые и организационные механизмы, стимулирующие развитие инвестиционной деятельности для проведения в высших учебных заведениях и научных учреждениях исследований в медико-биологической отрасли. Развертывание связей в сорере коммерциализации научно-технических разработок стало приоритетом инновационной политики многих государств, а частно-государственные партнерства - действенным инструментом ее реализации, о чем свидетельствует рост расходов национальных бюджетов, законодательных инициатив и разработки новых программ.

В Украине, несмотря на определенные трудности последних лет, высокий научный потенциал в области медико-биологических наук обеспечивает рост количества наукоемких инновационных научно-технических разработок, коммерциализация которых, с учетом низкой инновационной активности научных учреждений и высших учебных заведений, требует системного государственного подхода, разработки стратегий, конкретных механизмов, способов и фрорм.

Ключевые слова: коммерциализация, трансфер технологий, научно-техническая деятельность, инновационный продукт, медико-биологическая отрасль.

The authors of this study confirm that the research and publication of the results were not associated with any conflicts regarding commercial or financial relations, relations with organizations and/or individuals who may have been related to the study, and interrelations of coauthors of the article.

Стаття надійшла 05.09.2020 р. Рекомендована до друку на засіданні редакційної колегії після рецензування 